\title{
Pengaruh Pola Asuh Orang Tua terhadap Efikasi Diri
}

\author{
Putu Putri Dena Laksmi ${ }^{1}$, Ni Wayan Suniasih ${ }^{2}$, Komang Ngurah Wiyasa3
}

1 Jurusan PGSD Universitas Pendidikan Ganesha Singaraja, Indonesia

${ }^{2}$ Jurusan PGSD Universitas Pendidikan Ganesha Singaraja, Indonesia

${ }^{3}$ Jurusan PGSD Universitas Pendidikan Ganesha Singaraja, Indonesia

\begin{abstract}
Abstrak
Penelitian ini bertujuan untuk mengetahui pengaruh pola asuh orang tua terhadap efikasi diri siswa kelas V SD Gugus I Gusti Ngurah Rai Kecamatan Denpasar Selatan tahun ajaran 2017/2018. Jenis penelitian ini adalah penelitian ex post facto, korelasional. Populasi dari penelitian ini adalah seluruh siswa kelas V SD Negeri yang ada di Gugus I Gusti Ngurah Rai Kecamatan Denpasar Selatan tahun ajaran 2017/2018 yang berjumlah 266 orang siswa. Penentuan sampel menggunakan teknik proportional random sampling dengan taraf kesalahan 5\% sehingga diperoleh banyaknya sampel dari populasi adalah 155 orang siswa. Data pola asuh orang tua dan efikasi diri dikumpulkan menggunakan metode angket dengan skala likert dan penskoran angket menggunakan politomi. Teknik analisis data menggunakan analisis regresi linier sederhana. Sebagai uji prasyarat adalah uji normalitas sebaran data dan uji linieritas. Berdasarkan hasil analisis data menunjukkan terdapat pengaruh positif pola asuh orang tua terhadap efikasi diri siswa kelas $\mathrm{V}$ dengan kontribusi nilai $\mathrm{R} 2=$ 0,035 atau sebesar 3,5\%. Persamaan model regresi efikasi diri $=65,89+0,34$ pola asuh orang tua. Persamaan regresi tersebut menjelaskan bahwa setiap kenaikan skor pola asuh orang tua akan menyebabkan kenaikan 0,34 peningkatan efikasi diri siswa pada konstanta 65,89 . Jadi dapat disimpulkan peningkatan dalam pola asuh orang tua dapat meningkatkan efikasi siswa.
\end{abstract}

\author{
Keywords: \\ pola asuh orang tua, \\ efikasi diri
}

\section{PENDAHULUAN}

Perkembangan anak sekolah dasar berada dalam periode transisi dari pertumbuhan pesat masa anak-anak ke tahap masa praremaja. Perubahan perkembangan mental maupun sosial menjadi ciri khas masa sekolah awal. Pada tahapan ini, anak dihadapkan pada berbagai perubahan yang terjadi dalam fase perkembangannya. Ada tiga aspek perkembangan pada masa anak sekolah dasar yang dikemukakan oleh Slavin (2011:101) yaitu; Perkembangan fisik, kognisi dan sosioemosi. Proses pemikiran anak juga mengalami perubahan penting periode peralihan dari tahap pemikiran praoperasi ke tahap operasi konkret. Memasuki tahap operasi konkret, anak-anak usia sekolah dasar dengan pesat mengembangkan kemampuan daya ingat dan kognisi, termasuk kemampuan meta-kognisi, yaitu kemampuan memikirkan pemikiran mereka sendiri dan mempelajari cara belajar. Siswa yang merasa yakin dengan kemampuannya menggunakan perilaku metakognisi dan motivasi diri mungkin akan mempunyai keyakinan yang tinggi. Keyakinan sebagai upaya diri anak itu sendiri menentukan keberhasilan atau kegagalannya. Namun, tidak semua anak mengalami peralihan pada usia yang sama, dan tidak satu pun anak berubah dari tahap satu ke tahap berikut dengan cepat. Hal ini disebabkan oleh faktor-faktor yang mempengaruhi perkembangan anak itu sendiri yang meliputi hereditas (keturunan/pembawaan) dan lingkungan perkembangannya.

Masalah akan muncul ketika anak tidak siap menghadapi kenyataan akibat dari ketidakyakinan akan diri dan kemampuan mereka sendiri, sehingga membuat mereka menjadi takut untuk pergi ke sekolah dan menutup diri dengan lingkungannya. Hal ini juga didukung oleh informasi yang didapat dari guru wali kelas V SD di Gugus I Gusti Ngurah Rai, didapatkan data bahwa sebagian besar anak yang memiliki masalah dalam belajar, seperti malu dalam mengutarakan pendapat, memiliki ketakutan untuk pergi ke sekolah, semangat belajar yang masih rendah, ragu-ragu dalam menjawab pertanyaan dari guru sehingga menyebabkan anak memiliki kecemasan yang berlebihan, hal ini disebabkan akibat dari ketidakyakinan terhadap apa yang ia kerjakan yang dalam hal ini dipengaruhi oleh lingkungan itu sendiri yang menyebabkan dalam fase perkembangan anak akan terganggu. Dalam perkembangan anak ada tugas 
perkembangan yang harus dapat dilalui anak seperti mereka di tuntut untuk dapat bergaul dengan temanteman sebaya, mengembangkan keterampilan dasar, dan belajar untuk mandiri membuat rencana yang bebas dari pengaruh orang tua dan orang lain. Maka dari pada itu, anak usia sekolah dasar perlu mengembangkan keyakinan dirinya sendiri bahwa mereka mampu melewati dan menjalankan perubahan-perubahan yang terjadi dalam dirinya. Keyakinan tersebut dikatakan sebagai efikasi diri. Sejalan dengan hal tersebut Albert Bandura (1997) berpendapat, efikasi diri mampu membuat seorang anak menentukan pilihan, seberapa besar usaha mereka untuk maju, kegigihan dan ketekunan yang mereka tunjukkan untuk menghadapi suatu permasalahan atau perubahan-perubahan yang terjadi di sekitarnya. Setiap orang percaya bahwa dirinya memiliki potensi untuk mengubah hal-hal yang ada di sekitarnya dan bertindak aktif dibandingkan oleh orang yang memiliki efikasi diri yang rendah. Lebih lanjut di jelaskan bahwa, pembentukan efikasi diri pada seseorang tidak terlepas dari peran lingkungan sekitar.

Awal pertumbuhan dari efikasi diri berkembang melalui peran orang tua, kemudian dipengaruhi oleh saudara kandung, teman sebaya, dan orang dewasa lainnya. Peran orang tua sangatlah penting bagi anak, karena anak akan menjadikan orangtua sebagai model bagi perilakunya. Ini berarti anak mengikuti perilaku orangtuanya, bahkan lebih dari itu anak juga akan mengikuti pandangan, pola pikir dan nilai-nilai yang dianut oleh orang tua. Jelaslah peran keluarga menjadi yang utama bagi perkembangan perilaku anak. Dengan demikian, keluarga merupakan lembaga sosialisasi yang pertama di dapat oleh anak dan menjadi hal yang utama dalam proses perkembangan anak.

Orang tua memiliki cara yang berbeda-beda dalam mendidik anaknya, salah satunya dengan menerapkan pola asuh. "Pola asuh orang tua merupakan segala bentuk dan proses interaksi yang terjadi antara orangtua dan anak" (Mulyadi, 2016:183). Apabila pola asuh orang tua dan interaksi dengan anggota keluarga yang lain baik, maka menjadi salah satu faktor pendukung pembentukan efikasi diri yang positif pada anak. Anak menjadi akan lebih mandiri dalam menyelesaikan permasalahan yang dihadapi. Maka dari pada itu, bahwa pola asuh orang tua menjadi salah satu faktor penentu pembentukan efikasi siswa.

Apsari Saraswati, Ika Zenita Ratnaningsih (2016) menyatakan, Hasil penelitian mengenai hubungan antara efikasi diri akademik dengan kematangan karir menunjukkan adanya sumbangan efektif sebesar 26,3\% yang diberikan efikasi diri akademik kepada kematangan karir pada siswa kelas XI SMK N 11 Semarang, sedangkan sisanya $73,6 \%$ dipengaruhi oleh faktor lain yang tidak diukur dalam penelitian ini. Rustika I Made (2012), Dalam penerapannya, teori efikasi diri yang dikemukakan oleh Albert Bandura mudah dapat diterapkan dalam berbagai bidang kehidupan. Dalam bidang psikologi perkembangan teori ini mudah dapat diterapkan karena sejalan dengan teori teori lainnya. Apabila dikaitkan dengan teori perkembangan Erikson, dimana dalam tahap-tahap perkembangan kepribadian manusia ada krisis-krisis psikososial yang harus dilalui seseorang akan dapat mencapai kematangan diri setelah mampu menyelesaikan krisis di setiap tahap perkembangan), maka teori efikasi diri yang menyatakan pentingnya peranan mastery experience dapat diterapkan dengan mudah dalam pengasuhan anak. Suroso (2014) Hasil analisis regresi ditemukan t regresi $=7,799$ dan korelasi parsial $=0,580$, dengan $p=0,000(p<0,01)$. Temuan ini menunjukkan adanya korelasi positif yang sangat signifikan antara dukungan orangtua dengan penyesuaian diri siswa. Sumbangan efektif variabel du- kungan sosial orangtua terhadap penyesuaian diri siswa sebesar 32,68 \%. Dengan demikian hipotesis kedua yang menyatakan ada hubungan positif antara dukungan sosial orangtua dengan penyesuaian diri diterima. Sufirmansyah (2015), Setelah melalui berbagai analisa, penelitian ini menghasilkan beberapa kesimpulan penting. Efikasi diri berpengaruh terhadap motivasi mahasiswa sebesar 50,2\%, dan sisanya 49,8\% dipengaruhi faktor lain. Motivasi berpengaruh terhadap prestasi belajar mahasiswa sebesar 29,9\%, dan sisanya 70,1\% dipengaruhi faktor lain. Efikasi diri berpengaruh terhadap prestasi belajar mahasiswa sebesar $67,4 \%$, dan sisanya 32,6\% dipengaruhi faktor lain. Sedangkan pengaruh efikasi diri terhadap prestasi belajar mahasiswa Pascasarjana Prodi PAI STAIN Kediri melalui motivasi sebagai variabel intervening menjadi sebesar $82,4 \%$, dan sisanya $17,6 \%$ dipengaruhi faktor lain.

Purwana Dedi (2016) Terdapat hubungan positif antara efikasi diri dengan minat berwirausaha sehingga dapat diintepretasikan bahwa efikasi diri akan mempengaruhi minat wirausaha. Semakin tinggi efikasi diri yang dimiliki akan semakin tinggi pula minat individu untuk berwirausaha, dan sebaliknya. Sebesar $26.6 \%$ variasi nilai minat berwirausaha dijelaskan oleh efikasi diri sedangkan sisanya $73.3 \%$ dijelaskan oleh variabel ain yang tidak dimasukan dalam model penelitian ini. Febriantin Eka (2016), Dari hasil analisis korelasi sederhana antara efikasi diri dengan kinerja, diperoleh koefisien korelasi sebesar 0,56 (ry1 = 0,56). Besarnya sumbangan atau kontribusi variabel efikasi diri dengan kinerja sebesar 0,31. Hal ini menggambarkan bahwa proporsi varians yang ada pada kinerja sebesar $31,1 \%$ dapat dijelaskan oleh varians yang ada pada efikasi diri. Selanjutnya pada pengujian korelasi parsial efikasi diri dengan kinerja dimana variabel pengambilan keputusan dikontrol, diperoleh 
koefisien korelasi sebesar 0,41 (ry1.2 = 0,41). Hasil ini menandakan bahwa walaupun variabel pengambilan keputusan dikontrol, hubungan antara efikasi diri dengan kinerja tetap positif. Dengan demikian efikasi diri merupakan variabel yang cukup stabil dalam meningkatkan kinerja.

Adapun tujuan penelitian ini yaitu: untuk mengetahui pengaruh pola asuh orang tua terhadap efikasi diri siswa kelas V SD Gugus I Gusti Ngurah Rai Tahun Ajaran 2017/2018.

\section{METODE PENELITIAN}

Penelitian ini termasuk jenis penelitian ex post facto dengan studi korelasional karena dalam penelitian ini hanya mengungkapkan gejala yang terjadi seperti apa adanya serta mengungkapkan faktorfaktor yang berpengaruh dari variabel bebas terhadap variabel terikat. Dalam penelitian ini dibahas mengenai seberapa besar pengaruh pola asuh orang tua terhadap efikasi diri. Pola asuh orang tua akan mempengaruhi keyakinan dan kepercayaan diri anak dalam hal ini efikasi dalam diri anak sehingga, anak dapat mandiri dan mampu mengembangkan kemampuannya sendiri.

Penelitian ini dilakukan bulan februari 2018 sampai dengan bulan mei 2018. Lokasi penelitian yaitu SD Negeri Gugus I Gusti Ngurah Rai Kecamatan Denpasar Selatan Tahun Ajaran 2017/2018. Populasi dalam penelitian ini adalah seluruh siswa kelas V SD Gugus I Gusti Ngurah Rai Kecamatan Denpasar Selatan. Terdapat 5 SD Negeri, yaitu SD Negeri 4 Sanur, SD Negeri 3 Sanur, SD Negeri 1 Sanur, SD Negeri 11 Sanur, SD Negeri 8 Sanur. Dengan jumlah populasi siswa kelas V sebanyak 266 Siswa.

Mengingat keterbatasan waktu dan dana dalam penelitian ini maka digunakan sampel penelitian. Penetapan besarnya sampel menggunakan teori R.V. Krecjie and D.W. Morgan dengan tabel untuk menentukan jumlah sampel yang diambil dari populasi secara random dengan tingkat ketelitian $95 \%$ dan taraf signifikansi 5\% untuk proporsi populasi (Agung, 2014). Populasi dalam penelitian ini sebanyak 266 siswa dengan laki-laki sebanyak 141 siswa dan perempuan sebanyak 125 siswa, sehingga banyaknya jumlah sampel sebanyak 155 siswa yang didasarkan pada tabel sebaran teori R.V. Krecjie and D.W. Morgan. Selanjutnya dicari tiap-tiap sampel dari sebaran populasi kelas V SD Gugus I Gusti Ngurah Rai Kecamatan Denpasar Selatan dengan teknik sampling yang digunakan yaitu proposional random sampling.

Metode pengumpulan data yang digunakan yaitu menggunakan nontes berupa angket dengan menggunakan model skala likert yang teknik penskorannya menggunakan politomi. Instrumen efikasi diri disusun melalui konstruk teori dari Albert Bandura (1997) dengan meninjau dari aspek dimensi efikasi yaitu; Level/magnitude, generality, dan strength. Angket yang disusun berdasarkan Morgan-Jinks Student Efficacy Scale yang telah di adaptasi dan di modifikasi sesuai dengan tata bahasa ketercernaan bahasa anak usia sekolah dasar yang terdiri dari item favorable dan item unfavorable. Instrumen pola asuh orang tua disusun melalui konstruk teori dari Baumrind dengan meninjau dari aspek dimensi pola asuh orang tua yaitu; kontrol dan responsivitas yang diberlakukan oleh orang tua berdasarkan gaya pengasuhan orang tua yang terbagi menjadi 3 tipe yaitu pola asuh authoritarian, permissive, authoritative. Angket yang disusun berdasarkan angket pola asuh orang tua yang disusun oleh Erlina (2016) yang kemudian disesuaikan dengan tata bahasa ketercernaan bahasa anak usia sekolah dasar yang terdiri dari item favorable dan item unfavorable.

Setelah instrumen angket efikasi diri dan pola asuh orang tua dibuat dilanjutkan dengan pengujian validasi teoritik dan validitas empiris. Uji coba dilakukan untuk mendapatkan gambaran secara empirik angket yang telah disusun layak untuk digunakan sebagai instrumen penelitian. Data penelitian yang sudah terkumpul selanjutnya akan dilakukan analisis data. Kegiatan analisis ini dilakukan setelah data dari seluruh responden dalam sampel dan sumber-sumber lainnya terkumpul. Setelah data terkumpul, data tersebut diolah dan dianalisis. Dalam penelitian ini, analisis data yang digunakan adalah analisis statistik inferensial. Berdasarkan rumusan masalah, uji hipotesis statistik pada penelitian ini dianalisis dengan menggunakan analisis regresi linier sederhana. Untuk bisa menggunakan analisis regresi linier sederhana harus memenuhi dua syarat terlebih dahulu, yaitu normalitas dan linieritas.

Uji normalitas dimaksudkan untuk memperlihatkan bahwa sebaran data sampel berdistribusi normal. Menurut Sugiyono (2017) uji normalitas data dilakukan untuk menentukan apakah data yang diperoleh dapat diuji dengan statistik parametrik atau tidak. Untuk menguji normalitas sebaran data digunakan formula Kolmogorov-Smirnov.

Asumsi kelinearan adalah persamaan linear $\mathrm{Y}=\mathrm{b} 0+\mathrm{b} 1 \mathrm{X}$ sesuai dalam menjelaskan pengaruh peubah bebas X terhadap peubah terikat Y. Uji lack of fit dapat digunakan untuk mengetahui apakah model regresi linear sesuai (fit) untuk menjelaskan pengaruh $\mathrm{X}$ terhadap $\mathrm{Y}$. Hipotesis yang diuji dalam penelitian ini adalah: Tidak terdapat pengaruh pola asuh orang tua terhadap efikasi diri siswa kelas V SD Gugus I Gusti Ngurah Rai Kecamatan Denpasar Selatan Tahun Ajaran 2017/2018. Setelah melalui uji 
prasyarat analisis dan terpenuhi dilanjutkan dengan uji hipotesis statistik dengan menggunakan analisis regresi linier sederhana.

\section{ANALISIS DAN PEMBAHASAN}

Data pola asuh orang tua siswa kelas V SD Gugus I Gusti Ngurah Rai Denpasar Selatan diperoleh dari data sekunder berupa penyebaran angket pola asuh orang tua. Sampel yang dibagikan angket pola asuh orang tua sebanyak 155 responden dan diberikan sebanyak 30 pernyataan. Berdasarkan data hasil skor pola asuh orang tua diperoleh skor tertinggi adalah 94 dan skor terendah adalah 70 . Dengan persentase kencendrungan anak yang diasuh akan digambarkan pada tabel 1.

Tabel 1. Persentase Kecendrungan Pola Pengasuhan

\begin{tabular}{cc}
\hline Pola Pengasuhan & Persentase Kecendrungan \\
\hline Authoritatif & $94 \%$ \\
Authoritarian & $5 \%$ \\
Permissive & $0,6 \%$ \\
\hline
\end{tabular}

Berdasarkan hasil analisis uji normalitas sebaran data pada taraf signifikansi 5\% dan dk (1- $\alpha$;n) diperoleh KStabel $=0,10$. Hasil analisis uji normalitas sebaran data pola asuh orang di dapatkan hasil KShitung 0,08. Karena KShitung 0,08 < KStabel 0,10, maka H0 diterima yang berarti data berdistribusi normal. Data efikasi diri siswa kelas V SD Gugus I Gusti Ngurah Rai Denpasar Selatan diperoleh dari penyebaran angket efikasi diri. Sampel yang dibagikan angket pola asuh orang tua sebanyak 155 responden dan diberikan sebanyak 30 pernyataan. Berdasarkan data hasil skor efikasi diri diperoleh skor tertinggi adalah 117 dan skor terendah adalah 69. Dengan persentase anak yang memiliki efikasi diri akan digambarkan pada tabel 2 .

Tabel 2. Persentase Efikasi Diri Siswa Kelas V SD Gugus I Gusti Ngurah Rai Kecamatan Denpasar Selatan

\begin{tabular}{cc}
\hline Dimensi Efikasi & Persentase Kecendrungan \\
\hline Level/magnitude & $27 \%$ \\
Generality & $22 \%$ \\
Strength & $51 \%$ \\
\hline
\end{tabular}

Berdasarkan hasil analisis uji normalitas sebaran data efikasi diri di dapatkan hasil $\mathrm{KS}_{\text {hitung }} 0,05$. Karena $\mathrm{KS}_{\text {hitung }} 0,05<\mathrm{KS}_{\text {tabel }}$ 0,10, maka $\mathrm{H}_{0}$ diterima yang berarti data berdistribusi normal. Berdasarkan uji linieritas pada taraf signifikansi $5 \%$ dan $\mathrm{dk}(\alpha, \mathrm{k}-2, \mathrm{n}-\mathrm{k})$ diperoleh $\mathrm{F}_{\text {tabel tc }}=1,70$. Hasil analisis uji linieritas di dapatkan hasil $F_{\text {hitung tc }} 1,58$. Karena $F_{\text {hitung tc }} 1,58<F_{\text {tabel tc }} 1,70$, maka $\mathrm{H}_{0}$ diterima yang berarti data linier.

Berdasarkan hasil uji normalitas dan uji linieritas dapat diketahui bahwa data yang diperoleh dari variabel pola asuh orang tua dan efikasi diri berdistribusi normal dan memiliki linieritas. Data yang diperoleh telah memenuhi uji prasyarat, maka uji hipotesis dilakukan dengan menggunakan analisis regresi linier sederhana. Berdasarkan perhitungan koefisien $b_{1}$ dan $b_{0}$ di dapatkan model regresi yakni Efikasi Diri $=65,89+0,34$ Pola Asuh Orang Tua. Untuk menguji signifikansi model regresi digunakan perhitungan dengan tabel 3. anava sebagai berikut.

Tabel 3. Hasil Perhitungan dengan Menggunakan Tabel Anava

\begin{tabular}{ccccccc}
\hline \multicolumn{7}{c}{ Tabel Anava } \\
Sumber & $\mathrm{db}$ & $\mathrm{JK}$ & $\mathrm{KT}$ & Fhitung & Ftabel \\
Regresi & 1 & 365,9 & 365,9 & 5,34 & 3,90 \\
Sisa & 153 & 10483,78 & 68,5 & & 1,70 \\
Lack of Fit (Tc) & 17 & 2592,6 & 152,5 & 1,58 & \\
Galat & 136 & 7891,22 & 96,4 & & \\
Total & 154 & 10850 & & & \\
& $\mathrm{R}^{2}$ & 0,035 & & & \\
\hline
\end{tabular}


Berdasarkan hasil analisis data diketahui antara pola asuh orang tua $(\mathrm{X})$ dengan efikasi diri $(\mathrm{Y})$ siswa kelas V SD Gugus I Gusti Ngurah Rai Kecamatan Denpasar Selatan Tahun Ajaran 2017/2018 dengan nilai $F_{\text {hitung regresi }}=5,34$, dan $F_{\text {tabel regresi }}=3,90(n=155)$ pada taraf signifikansi $5 \%$ dengan db (regresi) 1 menerima $\mathrm{H}_{\mathrm{a}}$ yang menyatakan terdapat pengaruh pola asuh orang tua terhadap efikasi diri siswa kelas $\mathrm{V}$ SD Gugus I Gusti Ngurah Rai Kecamatan Denpasar Selatan Tahun Ajaran 2017/2018 dengan koefisien determinasi $\mathrm{R}^{2}=0,035$. Jika dipersentase, $\mathrm{R}^{2}(0,035) \times 100 \%$ di peroleh hasil sebesar $3,5 \%$ artinya pola asuh memberikan kontribusi efikasi diri sebesar $3,5 \%$.

Berdasarkan hasil pembahasan di atas pola asuh orang tua memberikan kontibusi efikasi diri sebesar 3,5\%. Pemberian perlakuan dan pengasuhan yang tepat akan meningkatkan efikasi anak tersebut. Lewat lingkungan keluarga yang baik awal pembentukan efikasi anak akan dapat ditingkatkan. Hal tersebut juga berkaitan erat dengan sumber efikasi yang menyebutkan bahwa anak akan cenderung mengikuti model sosial serta dukungan sosial dari orang terdekat dan paling lekat dengan kehidupan anak yakni orang tua. Orang tua akan sebagai figur pertama yang akan diamati oleh anak. Apabila sosok figur yang diamati memiliki keberhasilan dan mendukung anak, maka akan cenderung memiliki efikasi yang tinggi, sebaliknya efikasi diri akan menurun jika figur yang diamati oleh anak memiliki kegagalan dan kurang mendukung anak. Jelas maka efikasi diri dapat ditingkatkan dan diturunkan oleh dukungan dan peran orang tua. Lebih lanjut ada beberapa faktor yang mempengaruhi efikasi anak itu sendiri yakni dari budaya yang dianut oleh orang terdekat anak yang dapat memberikan penilaian efikasi anak apakah anak tersebut tinggi atau rendah. Kemudian berdasarkan gender yang mempengaruhi efikasi diri. Anak perempuan cenderung memiliki efikasi diri yang tinggi dibandingkan anak laki-laki karena anak perempuan dapat mengelola tugas-tugas yang diberikan dibandingkan anak laki-laki. Selanjutnya bedasarkan sifat tugas yang dihadapi, kecendrungan insentif eksternal, Status atau peran anak tersebut dalam lingkungannya, dan informasi tentang kemampuan dirinya baik positif maupun negatif sama-sama memiliki kecendrungan untuk dapat meningkatkan atau dapat menurunkan efikasi diri anak. Efikasi diri memiliki kaitan yang erat dengan orang tua terutama terletak bagaimana anak tersebut di berikan perlakuan maupun pengasuhan. Pemberian perlakuan dan pengasuhan yang tepat akan meningkatkan efikasi anak tersebut.

Hal tersebut didukung oleh pendapat dari Bandura (1997) yang menyatakan bahwa ada beberapa faktor lain mempengaruhi efikasi diri pada individu selain pola pengasuhan orang tua antara lain; 1 ) budaya; budaya dapat mempengaruhi efikasi diri melalui nilai, kepercayaan, dan proses pengaturan diri yang berfungsi sebagai salah satu sumber penilaian efikasi diri dan sebagai konsekuensi dari keyakinan akan efikasi diri siswa tersebut. 2) gender; perbedaan gender juga dapat mempengaruhi efikasi diri siswa hal ini berkaitan dengan bagaimana individu tersebut mengelola perannya. Anak perempuan terbiasa untuk membantu tugas dari ibunya dirumah hal ini berbanding terbalik dengan anak laki-laki yang cenderung tidak terbiasa untuk membantu ibunya. Maka daripada itu anak perempuan cenderung memiliki efikasi diri yang tinggi dibandingkan dengan anak laki-laki. 3) sifat dari tugas yang dihadapi; apabila anak ditugaskan mengerjakan pekerjaan yang menurut mereka rumit anak akan cenderung menilai bahwa ia tidak mampu menyelesaikan pekerjaan tersebut. Berlaku juga sebaliknya apabila anak tersebut ditugaskan mengerjakan pekerjaan yang mudah dan sederhana bagi mereka. Maka anak tersebut akan tinggi menilai kemampuannya sehingga akan menyebabkan efikasi diri anak tersebut meningkat. 4) insentif eksternal; pemberian hadiah, dukungan serta motivasi yang tepat maka akan dapat meningkatkan efikasi siswa tersebut. 5) status atau peran anak dalam lingkungan baik lingkungan keluarga, sekolah, dan masyarakat. Apabila anak berada dalam situasi ia diperhatikan dan disayang anak tersebut akan merasa bahwa dirinya berarti sehingga akan meningkatkan efikasi diri anak tersebut serta yang terakhir yaitu, 6) informasi tentang kemampuan dirinya, apabila anak diberikan informasi yang positif mengenai kemampuan dirinya maka akan meningkatkan efikasi diri anak tersebut. Berlaku juga sebaliknya apabila anak mendapatkan informasi yang negatif mengenai kemampuan dirinya tanpa adaya dukungan dari orang terdekatnya maka efikasi diri anak akan menurun dan cenderung rendah menilai dirinya. Selain itu Bandura menyebutkan bahwa selain faktor-faktor yang mempengaruhi diatas adapula sumber-sumber yang dapat menurunkan dan meningkatkan efikasi diri siswa. Seperti pengalaman anak tersebut di masa lalu apabila anak tersebut memiliki keberhasilan di masa lalu anak akan mulai menekuni dan menjadikan hal tersebut bagian dari kegemaran anak tersebut. Berbanding halnya apabila anak tersebut mengalami kegagalan maka anak akan cenderung menghindari hal tersebut. Selanjutnya yakni pengalaman vikarius yang diperoleh dari model sosial, persuasi sosial dan keadaan emosi anak tersebut. Jelaslah bahwa efikasi diri anak dapat meningkat dan menurun bergantung kepada bagaimana anak tersebut menilai kemampuan dirinya. Maka dari pada itu perlu adanya dukungan serta motivasi dari lingkungan sekitar 
siswa untuk dapat memberikan semangat untuk meyakinkan siswa tersebut dapat melewati berbagai permasalahan serta tantangan yang dihadapi.

\section{KESIMPULAN}

Berdasarkan hasil analisis dan pembahasan dapat disimpulkan bahwa terdapat pengaruh pola asuh orang tua terhadap efikasi diri siswa kelas V SD Gugus I Gusti Ngurah Rai Kecamatan Denpasar Selatan Tahun Ajaran 2017/2018. Hal ini di buktikan dengan hasil Fhitung regresi = 5,34 dan Ftabel regresi = 3,90 yang berarti Fhitung regresi $=5,34>$ Ftabel regresi $=3,90$, sehingga Ha yang menyatakan terdapat pengaruh yang signifikan pola asuh orang tua terhadap efikasi diri siswa kelas V SD Gugus I Gusti Ngurah Rai Kecamatan Denpasar Selatan tahun ajaran 2017/2018 diterima. Nilai Fhitung regresi $=5,34$ tersebut juga menunjukkan bahwa terjadi pengaruh positif pola asuh orang tua terhadap efikasi diri siswa. Koefisien determinasi menunjukan sebesar 3,5\% variasi efikasi diri ditentukan oleh pola asuh orang tua. Berdasarkan hasil analisis tersebut dapat diinterpretasikan bahwa, pola asuh berpengaruh terhadap efikasi diri. Hal ini dibuktikan dari pola asuh orang tua memiliki kontribusi 3,5\% terhadap efikasi siswa. Artinya ada faktor yang mendominasi selain faktor pola pengasuhan orang tua. Berdasarkan dengan teori yang di kemukakan oleh Bandura bahwa ada faktor lain yang mempengaruhi seseorang. Namun yang jelas bahwa efikasi diri seseorang bergantung kepada bagaimana orang tersebut menilai kemampuannya.

Adapun saran yang dapat disampaikan berdasarkan hasil penelitian yang telah dilakukan yaitu: untuk orang tua agar dapat memberikan contoh yang baik, dukungan dan kasih sayang agar anak dapat mengembangkan efikasi diri yang positif. Karena anak belajar dari pengamatan orang tedekatnya, sehingga anak perlu untuk mendapatkan lingkungan yang baik untuk dipelajari dan ditirunya. Lewat pengasuhan yang baik dan tepat maka anak akan dapat mengembangkan efikasi diri secara maksimal. Selain itu perlu peran dari guru agar dapat memberikan dukungan, motivasi dan perhatian kepada siswa. Karena peran serta guru di sekolah juga sangat menentukan pembentukan efikasi diri pada siswa. Guru dapat menciptakan suasana pembelajaran yang menyenangkan sehingga membuat siswa menjadi nyaman dan termotivasi untuk beradaptasi dengan lingkungan sekitarnya.

\section{DAFTAR PUSTAKA}

Agung, A.A.G. 2014. Buku Ajar Metodologi Penelitian Pendidikan. Yogyakarta: Aditya Media Publishing.

Alwisol. 2014. Psikologi Kepribadian Edisi Revisi. Malang: UMM Press.

Anwar, A.I. 2009. "Hubungan antara Self Efficacy dengan Kecemasan Berbicara di Depan Umum pada Mahasiswa Fakultas Psikologi Universitas Sumatra Utara".

Apsari Saraswati, Ika Zenita Ratnaningsih. 2016. Hubungan antara Efikasi Diri Akademik dengan Kematangan Karir pada Siswa Kelas XI SMK N 11 Semarang. Jurnal Empati Universitas Diponogoro. Volume 5 Nomor 3. P430-434.

Baumrind, Diana. 1966. Effects of Authoritative Parental Control on Child Behavior. Child Development. 37 (4), 887 - 907.

Baumrind, Diana. 1991. The Influence of Parenting Style on Adolescent Competence and Substance Use. Journal of Early Adolescense. 11 (1), 56 -59.

Bandura, A. 1977. Self-efficacy: Toward a Unifying Theory of Behavioral Change. Psychological Review. Vol.84, No.2 (hlm.191-215).

Bandura, A. 1997. Self-Efficacy The Exercise of Control. New York: W.H. Freeman and Company.

Erlina, Winda. 2016. "Pola Asuh Orang Tua sebagai Prediktor Kecerdasan Emosional pada Remaja”.

Febriantin Eka. 2016. Hubungan antara Efikasi Diri dan Pengambilan Keputusan dengan Kinerja. Jurnal Manajemen Pendidikan UNJ. Volume 1 Nomor 1.

Jinks, J. \& Morgan, V. (1999). “Children’s perceived academic self-efficacy: An inventory scale”. Vol.72, No. 4 (hlm 224-230). 
Kusrieni Devi. 2014. Hubungan Efikasi diri dengan perilaku menyontek. Psikopedagogia Jurnal Bimbingan dan Konseling Universitas Ahmad Dahlan. Vol 3 (2).

Mulyadi, Seto, dkk. 2016. Psikologi Pendidikan akan Pendekatan Teori-Teori Baru dalam Psikologi. Jakarta: Rajawali Pers.

Purwana Dedi. 2016. Efikasi Diri dan Pengaruhnya terhadap Intensi Berwirausaha Karyawan. Jurnal Ilmiah Econosains UNJ. Vol. 14 No. 1.

Rustika I Made. 2012. Efikasi Diri: Tinjauan Teori Albert Bandura. Jurnal Buletin Psikologi Universitas Gadjah Mada. Volume 20, No. 1-2, P:18 - 25.

Santrock, John W. 2007. Perkembangan Anak, edisi kesebelas, jilid I. Terjemahan Mila Rachmawati dan Anna Kuswanti. Jakarta: Erlangga.

Santrock, John W. 2007. Perkembangan Anak, edisi ketujuh, jilid II. Terjemahan Mila Rachmawati dan Anna Kuswanti. Jakarta: Erlangga.

Slavin, Robert E. 2011. Psikologi Pendidikan Teori dan Praktik. Jakarta: Indeks.

Sufirmansyah. 2015. Pengaruh Efikasi Diri terhadap Prestasi Belajar Mahasiswa Pascasarjana Prodi Pai Stain Kediri Dengan Motivasi Sebagai Variabel Intervening. Jurnal Didaktika Religia STAIN Kediri. Volume 3, No. 2.

Sugiyono. 2017. Statistika untuk Penelitian. Bandung: Alfabeta.

Suroso. 2014. Efikasi Diri, Dukungan Sosial dan Penyesuaian Diri dalam Belajar. Persona, Jurnal Psikologi Indonesia. Vol. 3, No. 02, p183 - 194.

Taylor, Shelley E, dkk. 2009. Psikologi Sosial. Jakarta: Kencana.

Yusuf, Syamsu. 2017. Psikologi Perkembangan Anak \& Remaja. Bandung: Remaja Rosdakarya. 